Revista Iberoamericana. Vol. LXV, Núm. 187, Abril-Junio 1999; 267-280

\title{
DISPERSIONES DEL GENERO: \\ HISPANISMO Y DISIDENCIA SEXUAL EN AUGUSTO D'HALMAR
}

POR

\author{
SyLVIA MolLoY \\ New York University
}

\begin{abstract}
Viajábamos para encontrarnos con nosotros mismos y para encontrar la nacionalidad superior.

Manuel Ugarte, Escritores iberoamericanos de 1900
\end{abstract}

[Y]o no enuncio, sino anuncio, y todas mis palabras, desprovistas a veces de sentido, escóndenlo doble y son otras tantas anticipaciones.

Augusto D'Halmar, El reportaje que nadie nos hace nunca

Algo que lamento es no poderme vestir de turco en Santiago. Augusto D'Halmar, en Joaquín Edwards Bello, Recuerdos de un cuarto de siglo

Refiriéndose a políticas culturales de los años veinte en Hispanoamérica (a la vez que intenta justificar sus amoríos con una bailarina española), escribe Vasconcelos en el Ulises criollo:

En aquel tiempo el baile español era el filtro de una reconciliación dionisíaca con nuestro pasado hispánico. En medio de aquel oleaje de los usos yanquis invasores y después de casi un siglo de apartamiento enconado, bebíamos con afán en la linfa del común linaje. Lo que no lograba la diplomacia, lo que no intentaban los pensadores, lo consumaba en un instante el género flamenco (305).

Si la memoria no me engaña esta reconciliación, en versión un tanto desmejorada, seguía vigente en los años cuarenta en Buenos Aires como, supongo, en otros países hispanoamericanos. Recuerdo las academias de baile bonaerenses, academias que se anunciaban como de "Baile clásico y español" pero cuya verdadera vocación, a juzgar por el ruido de castañuelas y el enérgico taconeo que se filtraban por las ventanas, estaba más del lado de las sevillanas que de los pas de deux. También recuerdo los avisos de disfraces de carnaval para chicos, donde además de "El Gaucho", "La China", "La Marquesa" o "El Pirata", figuraba prominentemente la bailarina española con su inevitable traje rojo. Todo esto ocurría en la muy cosmopolita Buenos Aires, de pretensiones culturales marcadas más por Francia o Inglaterra que por su antigua metrópoli, donde los españoles seguían siendo gallegos y, en consecuencia, blanco de chistes. Algo parecido ocurría, sospecho, en más de 
un país hispanoamericano. Los poderes heroicos del flamenco como barrera contra la invasión yanqui ( si es que alguna vez funcionó de ese modo), el aura de la bailarina española y sus castañuelas como símbolo de una tradición hispánica casi mística. por cierto se había degradado. Se seguía recordando a "La Argentina", se seguía diciendo que García Lorca había dado nueva vigencia a lo gitano, pero el baile español, las castañuelas, el flamenco, habían entrado de una vez por todas en el ámbito de lo cursi. De dudosa jerarquía, culturalmente hablando, por cierto no cumplían la función heroica que quería para ellos Vasconcelos, la de ser símbolos de una comunidad hispanoamericana.

Quiero demorarme un instante en la noción del flamenco como ícono cultural degradado (degradación, por otra parte, que había comenzado mucho antes de Vasconcelos, en el siglo diecinueve y en la misma España) y pensar en la posibilidad de una solidaridad basada en la degradación, incluso en la cursilería. Porque ya en los años cuarenta - en la época misma en que las niñitas aprendían el difícil arte de las castañuelas- el flamenco, y el baile español en general, se había vuelto, por lo menos en la Argentina, símbolo (y espacio cultural) de una comunidad muy otra. El teatro Avenida de Buenos Aires, espacio privilegiado por las compañias de baile y zarzuela españolas, se había vuelto también espacio de encuentros homosexuales y fue escenario, en 1943, del segundo escándalo homosexual más publicitado del siglo, siendo el primero el escándalo de los cadetes del Colegio Militar algunos años antes. Si bien la razzia del Teatro Avenida condujo a la deportación de una compañía entera de baile, la de Miguel de Molina, arrojó un saldo inesperado al dar visibilidad a una subcultura homosexual hasta entonces silenciada. Así como se disfrazaban de bailarina española las chicas también los chicos: la bailarina española, con su traje rojo y bata de cola, se volvió rol preferido de los travestis hispanoamericanos, como lo atestigua con garbo y valentía la Manuela en El lugar sin límites de José Donoso.

Dentro de este movimiento vertiginoso que va de lo heroico a lo cursi - el mítico ícono comunal, "nuestra España sobre-territorial" como la llamaba Unamuno (429), vuelto signo subversivo- quiero reflexionar por un momento sobre el peso ideológico (e inestabilidad ideológica) de lo hispano, construcción heterogénea de notable eficacia desde fines de siglo hasta los años veinte. Con la posible excepción de Puerto Rico y Cuba, países recién independizados de España, donde la cercanía de lo hispano todavía incomodaba, la mayoría de los países hispanoamericanos a fines de siglo habían disociado suficientemente lo político de lo estético en el dominio de lo español como para poder ver ambos procesos, el político y el estético, con luz nueva. Incluso puede decirse que antes de la independencia - pienso en los versos de Martí sobre la bailarina española- ya se daba esa disociación. En el campo de lo estético, los artefactos culturales de España, gracias a la poética revisionista del modernismo y su reapropiación de la espagnolade francesa, cobró nueva vida. En el campo de lo político, fue necesario un traslado más complejo. Si bien es cierto que los festejos del centenario a través de Hispanoamérica recrearon la escena de ruptura con España, también es verdad que España, esta vez, fue parte de la conmemoración y acudió al banquete. Fue éste literalmente el caso en la Argentina, donde ya para 1900, por decreto presidencial, se había eliminado del himno nacional toda referencia ofensiva a España y donde la misma Infanta Isabel de Borbón fue invitada de honor en los festejos conmemorativos. Así la retórica del centenario recupera a España, no ya como poder 
colonial que la independencia ha dejado atrás sino como simulacro de orígenes, como raíz fantasmática que unía a las naciones hispanoamericanas dotándolas de una tradición común que las distinguía tanto de la Europa decadente como de los pragmáticos vecinos del norte. Lo hispano permitía el acceso de esta otra América a una casi mística latinidad, era sinónimo de la abarcadora (aunque discriminatoria) noción de raza. No sorprende entonces que, a pesar de la aparente paradoja, algunos de los nacionalistas más apasionados de los años veinte y treinta, al igual que Vasconcelos, se empeñaran en ver lo hispano ya no como señal de dependencia sino como comienzo de una nueva unión. Hay que añadir que en la mayoría de los casos este reclamo ideológico del hispanismo, además de pretender contribuir a la construcción de identidades estables, ya fueran nacionales o continentales, favorecía la xenofobia, el racismo y, específicamente, el antisemitismo.

Esta reevaluación conservadora de lo hispano provee el contexto de lectura de cuatro novelas, publicadas entre 1908 y 1924, a saber La gloria de don Ramiro de Enrique Larreta (1908), El embrujo de Sevilla de Carlos Reyles (1922), Pasión y muerte del cura Deusto de Augusto D'Halmar (1924), y Un chileno en Madrid de Joaquín Edwards Bello (1928). Las cuatro transcurren en España, aunque en diferentes regiones, las cuatro intentan reanimar lo hispano como herencia vital. Sólo una de estas novelas, Pasión y muerte del cura Deusto, tiene una anécdota específicamente homoerótica - hecho excepcional en sí y, dentro de la recuperación programática de España, una verdadera aberración. Quiero detenerme en esa aberración y en la luz que inesperadamente arroja sobre el proceso revisionista. Pero antes quiero repasar algunos aspectos del propio Augusto D'Halmar.

A pesar de haber sido saludado por Hernán Díaz Arrieta como uno de "los cuatro grandes" de la literatura chilena, Augusto D'Halmar es un autor prácticamente desconocido salvo para los chilenos, los estudiosos de la literatura chilena y algunos pocos aficionados entre los que me cuento. No vacila Díaz Arrieta en afirmar que "No es excesivo hablar de una época de nuestra literatura anterior a D'Halmar y de otra posterior, que él presidió, por lo menos, al principio, cuando había que abrir las puertas, señalar horizontes y salir al mundo" (Díaz Arrieta 18). Díaz Arrieta no especifica la innovación de D’Halmar (qué puertas, qué horizontes, qué mundo); otros críticos aluden a ella en términos cifrados: "La figura de D'Halmar asume contornos de precursor [...] D'Halmar señala [...] para nuestra generación y la siguiente, el camino por donde de Loti se pasa a Proust" (Montenegro 15). Y cuando sí se habla de la homosexualidad de D'Halmar, se lo hace con reticencia. Díaz Arrieta menciona "algo [...] que hasta ahora nadie ha dicho claramente, aunque todos lo saben: el uranismo de D'Halmar, que no lo explica todo, pero sin lo cual nada se entiende" (19), observa que es "el drama íntimo del escritor, su abismo secreto" (12), y reduce la homosexualidad de D'Halmar a la categoría de chisme vergonzoso: "Su categoría acallaba las murmuraciones. Y también su estampa, su entonación viril, su prestancia resuelta" (12). Yo propongo en cambio que esa misma homosexualidad, expresada a lo largo de la obra de D'Halmar, ya directamente, como en Pasión y muerte del cura Deusto, ya oblicuamente, como en muchos otros de sus textos, constituye su contribución más importante a la literatura. 
Nacido en Chile en 1882, Augusto Goémine Thomson (por lo menos en una de las muchas versiones que ofrece de su vida) fue hijo ilegítimo de una chilena de buena familia y de un marino francés que luego de pasar corto tiempo en Chile se marchó para nunca volver. Rebelde y dandy, afecto a las poses literarias que concebía como pronunciamientos políticos, el joven Thomson es responsable de uno de los experimentos más interesantes de Hispanoamérica a comienzos de siglo, la creación de una comunidad masculina utópica en el sur de Chile a la que dio el nombre de Colonia Tolstoyana en homenaje al maestro. Los miembros de la colonia eran cuatro: el propio Thomson, Fernando Santibáñez, joven escritor que se autodescribe como "el amigo, el discípulo, el reverente protegido" de Thomson (Santiván 1460), y dos pintores. La comuna no duró más de un año, por razones que no examinaré aquí. Durante ese tiempo, entre 1904 y 1905, Thomson adoptó el seudónimo de D'Halmar. Diría años después que era el apellido de un antepasado sueco; más interesante es quizá observar que se trataba, al principio, de un seudónimo compartido, elegido por él y Santibañez para una escritura en colaboración: Augusto y Fernando Halmar.' La disolución de la colonia coincide con el final de la amistad, según acontecimientos que recurren una y otra vez, ficcionalizados, en la obra de D'Halmar, notablemente en la trama claramente alusiva de La lámpara en el molino: dos hombres, unidos por una tierna amistad, se distancian cuando uno de ellos se enamora de la hermana del otro. Santibáñez (que pasaría a tomar el seudónimo, también tolstoyano, de Santiván) se casa con la hermana de Thomson y rompe el lazo que une a los dos hombres. Thomson se queda con el seudónimo y cabe especular que, con exquisita ironía de sobreviviente, añade la partícula (signo ya de aristocracia ya de conyugalidad) a la vez que reclama el nombre para sí: D'Halmar. El seudónimo que había marcado la plenitud de la colaboración masculina, la "perfecta amistad", era ahora un signo para siempre medio vacante, un permanente recuerdo de la pérdida. $^{2}$

De esa pérdida nace el escritor D’Halmar, producto de una hábil autofabricación o, como él mismo declara en una entrevista paródica que se hace a sí mismo, "un autor que ha logrado el milagro de 'recrearse a sí mismo' en el doble sentido de volverse a crear o procrear y en el de sentir con fruición sus propias creaciones" (Antología 234). ${ }^{3}$ Esta cuidadosa autoconstrucción programática, consolidada por la elección del seudónimo, produce cierta ansiedad por parte de los críticos: "Como si D'Halmar antes de crear sus obras de arte hubiese creado un d'Halmar en tan perfecta forma que el verdadero, el hombre, el autor de su técnica, desaparece" (Eduardo Barrios, en Espinoza 13). Propongo en cambio que el seudónimo se vea como la primera ficción de D’Halmar, más específicamente como su

\footnotetext{
1 "Augusto me había convencido de que deberíamos colaborar, a semejanza de aquellos célebres hermanos Goncourt o de los saboyanos Erckmann-Chatrian: una amistad perfecta y desinteresada armonía literaria. Fue entonces cuando abandonamos nuestros nombres de Augusto G. Thomson y Fernando Sant-Iván, para adoptar el común seudónimo D'Halmar, precedido por los nombres Augusto y Fernando. Alcancé a firmar cuentos y artículos con este seudónimo. Pero no me sentía satisfecho" (Santiván 1515).

${ }^{2}$ Sobre homoerotismo y colaboración masculina, especialmente útil para leer a D'Halmar, ver Koestenbaum.

${ }^{3}$ En esa misma entrevista, "El reportaje que nadie nos hace nunca", D'Halmar imagina el diálogo siguiente: “- ¿Nombre? -El que me creé. — ¿Familia? - La que he adoptado" (Antología 235).
} 
primera ficción homoerótica: una ficción que cifra la pérdida, la imposibilidad de unión con el objeto amado, el deseo masculino y la fallida colaboración entre hombres no sólo en el texto mismo sino en la figura de su autor.

Texto fundador, el seudónimo es también una primera ficción de desplazamiento, el comienzo de una interminable errancia que es tema de la mayoría de los libros de D'Halmar. D'Halmar bien puede ser el nombre de un antepasado sueco pero es también al mar, llamado que el autor, después de su ruptura con Santiván, acata con furia. Cabe notar que después de una primera novela convencionalmente naturalista que transcurre en Chile, Juana Lucero, anterior a la experiencia de la colonia tolstoyana y a la adopción del seudónimo, D'Halmar no vuelve a ambientar ninguno de sus relatos en su país de origen. Tampoco reside demasiado en Chile después de 1905. Se hace nombrar cónsul general chileno en Calcuta en 1907 y permanece un año en la India. Por razones de salud pide traslado y vive en el norte del Perú de 1908 a 1915. En 1916, "por oscuras razones", como apunta delicadamente un crítico (Acevedo 35), se lo separa del servicio consular. Cubre la primera guerra mundial en Francia como corresponsal extranjero y luego (nuevamente después de insinuaciones de un asunto homosexual [Díaz Arrieta 33; Espinoza 22]), se marcha a España donde vive dieciséis años y escribe la mejor parte de su obra. Regresa pobre a Chile en el 34 , se dedica a revisar inéditos preparando sus obras completas, y ocupa insignificantes puestos de gobierno que le consiguen amigos. Al comienzo se lo recibe con entusiasmo, como el "hermano errante" (¿acaso errado?) de las letras chilenas pero pronto deja de ser objeto de celebración: "Aunque tan buen administrador de su renombre, sugestionador, magnetizador, hipnotizador, no pudo D’Halmar en Chile impedir la paulatina disminución del prestigio en que lo envolvía la distancia. La presencia real [...] lo limitaba" (Díaz Arrieta 3; subrayado mío). En 1942 se le otorga el flamante Premio Nacional de Literatura pero nadie se acuerda de invitarlo a la ceremonia. Muere en 1950.

El prestigio que brinda la distancia (y que el autor pacientemente cultiva) no es simplemente la del eterno viajero, animado por ansias indeterminadas sino, muy precisamente, el del viajero exótico, exponente del orientalismo eurocéntrico en su versión francesa, la más accesible en América Latina. ${ }^{4}$ Las frecuentes referencias de D'Halmar al Medio y Lejano Oriente, su supuesta familiaridad con el mundo árabe y, en general, el contacto del que se jacta con culturas a las que el chileno, y el latinoamericano medio, tenían escaso acceso, le ganaron una sólida reputación como una suerte de Pierre Loti sudamericano. Pero si todo orientalismo es cosa mental, el de Loti se vio avalado por un sostenido desplazamiento geográfico a través de los años como ofícial de la marina mercante francesa. Por el contrario, los viajes de D'Halmar son más modestos: su orientalismo parece adoptado de golpe, con la fuerza de una conversión religiosa, en el viaje que lo llevó a Asia vía Inglaterra, Francia y Egipto, en 1907. Exotismo traducido, adquirido más en lecturas de Loti (con quien D’Halmar pensaba tener más de un gusto en común y cuya presencia casi-mística en su vida

\footnotetext{
4 "La literatura colonial francesa constituye un desagradable tejido de clichés: tipologías físionómicas y caracterológicas del romanticismo, fantasías sexuales racistas, e imágenes detenidas, como tarjetas postales que se barajan al azar de marcos culturales indiscriminados, de sujetos nativos: negros, cobrizos, mestizos, asiáticos, árabes, kabiles, moros, turcos, beduinos, islámicos, bizantinos" (Apter 207, traducción mía).
} 
y obra describe más de una vez), ${ }^{5}$ que por experiencia directa, el orientalismo de D'Halmar tiene características particulares. Directamente evidente en textos inspirados por sus viajes a Egipto y la India, como Nirvana, Mi otro yo, y La sombra del humo en el espejo, no se basa en geografías precisas ni depende estrictamente del lugar. Podría decirse que la primera ficción orientalista que escribe D'Halmar es Gatita, novela corta donde el autor expone la que sería relación erótica preferida en su obra, el amor de un hombre mayor, de autoridad, por el niño colonizado y sexualmente ambiguo. Si bien la novela transcurre en el Perú, se trata de un Perú notablemente "oriental", en un pueblito que "lo mismo pudiera ser de la Palestina, o bien que aquel caserío estaba en Mahé, de Indias, o en Djibuti, del Africa"(Antología 174); un pueblito donde "la cal de los muros parecía tan brillante como en un arrabal de la Casbah" (176), y donde los habitantes mestizos exhiben "esa lasitud plañidera que han dejado los árabes en España y los españoles en América" (182). Este orientalismo desplazado y fluctuante encuentra su expresión más lograda en Pasión y muerte del cura Deusto, la novela que escribe D'Halmar desde y sobre ese otro país árabe que es España, intento del autor de reclamar lo hispano para Hispanoamérica y, a la vez, de subvertirlo.

Se dice que a D'Halmar le gustaba disfrazarse, aún antes de transformarse en "D'Halmar". Parece haber preferido los trajes sueltos, las capas: "Augusto permanecía durante el día vestido sólo con su camisón de dormir, lo que le daba cierta semejanza a joven faquir musulmán", escribe Santiván al evocar la época de la colonia tolstoyana, cediendo a su vez a la tentación orientalista (Santiván 1401). En "Pequeños pensamientos del destierro", al comentar su necesidad de "mudar de disfraz", observa D'Halmar: "No es un pueril exotismo de jugar al mameluco lo que me ha hecho insistir en mi tocado oriental, y si lo llevo es para conjurar no sé qué obscura suerte de la cual apenas si me atrevo a ocuparme" (Nirvana 106). D’Halmar parece haber gustado particularmente de sombreros y tocados "autóctonos". Refiriéndose a sí mismo en tercera persona, declara a su imaginario entrevistador: "Se sabe que ha llevado el fez osmanlí en el Oriente de los sultanes y en el Extremo Oriente el turbante hindú, que en España gasta capa y sombrero cordobés en Andalucía" (Antología 234). Llamo la atención sobre los tiempos verbales: vestirse de "Oriental" está en pasado, vestirse de "Español" en presente, el segundo disfraz prolonga el primero, sin solución de continuidad. Cabe preguntarse: ¿El disfraz de "Español" de D’Halmar también responde a la necesidad de "conjurar no sé qué obscura suerte de la cual apenas si me atrevo a ocuparme”? ¿Qué es España para D'Halmar?

D’Halmar evoca su decisión de mudarse a España, país en el que, después de Chile, viviría más tiempo, en términos significativos:

Y yo que, menos previsor que las bestias y hasta las alimanas, no tenía ni una madriguera que pudiera llamarse hogar, ni un simple agujero que me sirviera de patria, yo a quien no

\footnotetext{
${ }_{5}^{5}$ Abundan las referencias directas a Loti en la obra de D'Halmar. Véanse "Alrededor de Loti” y “Año Nuevo en Constantinopla" en la Antología y "Navidad en el mar" (texto en el que Díaz Arrieta agudamente ve una invocación de Loti como hermano espiritual) y "La vaga fecha" en Nirvana.
} 
esperaba nadie en ninguna parte y que no poseía sino todo el mundo y toda la vida, el pabellón unitario de los cielos y la desolada libertad de ser un hombre de doquiera, deseé limitarme, recluirme casi en algún punto que me fuere propicio. [...] Entonces pensé en España (Antología 222).

Y agrega: "[M]oralmente me he rehecho o, por ser más exacto, me ha rehecho moralmente España. Porque dentro de ella me he puesto en paz conmigo" (222).

España es lugar de restauración moral y de renovación personal, donde D'Halmar a quien le gustaba recalcar su vocación por el cambio y la autofabricación- se refacciona o, como escribe literalmente: Me he rehecho. Este refaccionamiento, marcado en un nivel por la capa y el sombrero andaluz, va acompañado por un deseo de estabilidad totalmente atípico en quien más de una vez dijo preferir el movimiento, la falta de límites, las identidades fluidas. ${ }^{6}$ Es obvio entonces que, sea cual fuere el papel del orientalismo en la construcción que hace D'Halmar de España - y por cierto lo tiene- ese orientalismo va acompañado por una retórica de búsqueda no sólo moral sino nacional: el yo refaccionado se instala en una orientalizada patria renovada.

El recurso a la noción de España como patria es, como he indicado, parte importante de una reflexión hispanoamericana en torno a los orígenes. D’Halmar no sólo está al tanto de la carga ideológica de esta empresa, la recalca en sus escritos: "Al evocar la patria ideal que recuperé, yo, el expatriado de todas, es de nosotros y de mí mismo que me ocupo, de la raza inmanente, del pasado común, del porvenir que nos preocupa y cuya gestación fermenta en cada uno y en todos" (Antología 222) noción que a menudo repite en escritos periodísticos de la época. ${ }^{7}$ En su reseña de Un chileno en Madrid, novela de su compatriota Joaquín Edwards Bello, alaba a Edwards Bello por esa "idea fija de criollo que, por amor a su tierra de porvenir, vuelve hacia la del pasado, como quien remonta al manantial y advierte, no sólo que no está exhausto, sino que es más puro que el restante curso de agua" ("Edwards Bello" 500). Y sin embargo es en esa misma España, vuelta fantasmática casa familiar, en ese lugar común hispánico, donde D’Halmar sitúa su ficción más explícitamente homoerótica. Es como si, luego de haberse desarraigado de Chile y optado por una vida errante, orientalizándose en el curso de su deriva, D'Halmar necesitara repensar lo hispano al igual que otros hispanoamericanos, pero en sus propios términos. Esos términos precisos - esto es, la proyección del homoerotismo en el corazón mismo de la patria, cuestionando así convenciones hispánicas acerca del género-atestiguan desde luego las limitaciones de esa misma patria y el precario lugar que D'Halmar ocupa en ella.

Como El embrujo de Sevilla de Carlos Reyles, la novela de D'Halmar transcurre en Sevilla. A diferencia de Reyles, "creyente fervoroso en las virtualidades de aquella tierra bravía y soñadora" (Reyles 10), quien sitúa su anécdota heroica en el siglo diecinueve,

\footnotetext{
"A la pregunta "¿Qué le abruma?" que se hace D’Halmar al entrevistarse a sí mismo, responde: "La obsesión del yo y del nombre específico. La imposibilidad de anegarme y disolverme [...]" (Antología 238).

${ }^{7}$ Durante su estancia en España, D'Halmar es colaborador asiduo del periódico Informaciones. Entre 1925 y 1928, escribe con regularidad para La Nación de Santiago, contribuyendo artículos esencialmente descriptivos sobre España que luego publica en volumen titulado La Mancha de Don Quijote (1934).
} 
D'Halmar ubica la suya plenamente en el siglo veinte, logrando el exquisito malestar de ciertas descripciones de Roma de D'Annunzio (pienso sobre todo en Il Piacere) provocado por el contacto entre dos mundos, el pastoril y el tecnológico: el niño montado en burro junto a la Hispano-Suiza. La novela narra la historia de un cura vasco quien, desconsolado porque su mejor amigo del seminario se casa con su hermana — situación ya habitual en D'Halmarpide ser trasladado a una parroquia lejana y termina en Sevilla. ${ }^{8}$ Allí conoce a Pedro Miguel, "El Aceitunita", gitanillo de origen morisco y judío que lo orienta en el mundo andaluz. Miembro del coro de la iglesia, monaguillo, acaba siendo - como los adolescentes en Gatita y La sombra del humo en el espejo- objeto de un amor que el cura se niega a aceptar. La anécdota se estructura según dos líneas: la resistencia de Deusto a admitir la existencia de este amor que todos reconocen pero que nadie nombra, y el descubrimiento que hace el adolescente de su propia belleza y su poder de seducir. Sem Rubí, decadente pintor judío en cuya caracterización hay más de un recuerdo de los personajes de El retrato de Dorian Gray, logra que el muchacho le sirva de modelo, a la vez que lo inicia en el mundo del flamenco, los toros, la vida fácil y la ambigüedad sexual. Cuando el muchacho, cansado de esa vida, regresa a Deusto, ya consciente de los sentimientos que lo unen al hombre mayor, se da el reconocimiento recíproco: "Entonces comprendieron los ojos negros y los ojos verdes, que nunca se habían mirado hasta entonces. Y era delicioso y a la par terrible. Quien haya mirado una sola vez así en la sombra, no debiera volver a ver la luz" (Pasión 200)." El joven decide partir, dándose cuenta de que "lo nuestro" carece de futuro: "me voy sobre todo porque 'lo nuestro', como me lo hizo usted sentir anoche, no podía ya prolongarse" (219). Entonces, en una memorable escena de estación, el cura, luego de rechazar la invitación del joven a acompañarlo a Madrid para comenzar juntos una vida nueva, se arroja a las vías y se deja arrollar por el mismo tren en que se va el muchacho. La escena sin duda debe bastante al maestro en que se inspiró D'Halmar para su Colonia Tolstoyana. Curiosamente, este recurso Anna Karenina cierra otra novela hispanoamericana de la época que también reflexiona sobre lo hispano, el linaje y el homoerotismo: me refiero a El ángel de Sodoma (1929), del cubano Hernández Catá. El protagonista de esa novela, tan culpabilizado y desesperado como el cura de D’Halmar (y además patologizado por un

${ }^{8}$ El bovarismo místico que comparten los dos seminaristas no puede sino recordar la apasionada relación entre D'Halmar y Santiván en la Colonia Tolstoyana. El pasaje merece ser citado in extenso:

[C]oncluirían su carrera, y, como Pedro María Alday, el otro, era huérfano, la madre y la hermana de Iñigo Deusto constituirian el hogar de los jóvenes; llenarian su ministerio sin separarse, harian mucho bien, su común afición por la música contribuiria a vincularlos y llevarian a cabo cosas muy bellas ... Todo bajo esta lámpara tutelar que ahora, acá en Sevilla, esclarecía dulcemente los rasgos de otro Pedrucho más joven y de un envejecido Deusto.

[...] Pero vino a morir la madre, y un día Pedro María hubo de confesar a Iñigo su amor por su hermana, que le impediria pronunciar sus votos; entraría, pues, en la familia, sólo que de cuán distinto modo! Y Deusto comprendió que no eran únicamente sus proyectos infantiles los que salian heridos de muerte por esta trivial materialización, sino qué sé yo qué recóndito pudor, qué idea! imposible de perfección.

No habian vuelto a verse casi con los jóvenes esposos (39).

'D'Halmar se detiene con frecuencia en la mirada entre hombres. Para dar un solo ejemplo, de Pasión $y$ muerte: "[E]n ese momento, una chispa pareció recorrerle y se quedaron fijos sus ojos, porque acababa de recoger la mirada de Deusto clavada en él, desde la galería. Titubeó un momento, y con una voz dolorida improvisó la última endecha, que no se dirigía sino a él" (163). 
prólogo de Gregorio Marañón), se arroja a las vías del metro de París antes de consumar un amor que lo culpabiliza.

Como novela homosexual, Pasión y muerte del cura Deusto pertenece sin duda a la modalidad trágica: hay mucha angustia, mucha indagación interior, mucho nombrar-sinnombrar - "Cómo permanecer aquí, donde todos dicen que somos ... lo que no somos?" (221) - mucha vergüenza y un suicidio al final. Este suicidio permite medir, de hecho, la distancia entre esta novela y las ficciones homoeróticas que ya lleva escritas D'Halmar. Gatita y La sombra del humo en el espejo eran textos básicamente elegíacos que celebraban una pederastía principalmente platónica; ${ }^{10}$ evitan el conflicto abiertamente homosexual y terminan no con muertes sino con separaciones (Sombra de modo muy semejante a la del episodio de Athman en Si le grain ne meurt de Gide). En cambio, Pasión y muerte, como otros relatos de Los alucinados donde el conflicto homosexual se hace patente (aunque permanezca innombrado), termina forzosamente en muerte, con el homosexual en papel de víctima sacrificial. Sería anacrónico pedirle a un escritor latinoamericano de los años veinte un tratamiento diferente del tema. " Pero además, el desenlace permite a D’Halmar apuntar a lectores distintos (e ideológicamente diversos). En este sentido es revelador su tratamiento ambiguo del Aceitunita. A veces se describe al muchacho como una calculadora "viborilla", atribuyéndole "la precocidad felina de los bohemios"(41); otras, como un ser cariñoso y honesto. Es como si el libro contara con dos comunidades de lectura y dos recepciones distintas, la una enjuiciadora, de lectores que necesitan ver al homosexual como viborilla y por ende portador de desgracia, la otra simpática, cómplice, de lectores entendidos que practican una lectura "entre nos" y se identifican con el desenlace patético. ${ }^{12}$

Lo que me interesa aquí es ver qué lugar ocupa este fracasado romance homosexual dentro de la nueva patria de D'Halmar. Porque España, para D'Halmar, es una fabricación infinitamente más compleja que la que proponen otros hispanoamericanos, Larreta o Reyles, digamos, arqueólogos literarios cuya recuperación de lo hispano, macerado en ideologías conservadoras, es relativamente simple. En cambio la España de D'Halmar es un mapa de geografías, ideologías y deseos encontrados. El protagonista de la novela viene del

\footnotetext{
${ }^{10}$ Elijo considerar Gatita como ficción homoerótica a pesar del hecho evidente de que el personaje homónimo es una niña. La composición que hace D'Halmar del personaje, la manera en que recalca su androginia, llamándola "una niña, un niño", y comparándola con un paje, la evocación de caricias sensuales y la carencia de escenas de amor heterosexual (se supone que la niña es amante del narrador), el paralelo explicito que establece D'Halmar entre Gatita y Zahir, el joven sirviente árabe de $\mathrm{La}$ sombra del humo en el espejo, justifican, creo, mi interpretación.

"Sólo se me ocurre un texto latinoamericano de la época donde la homosexualidad, una vez descubierta, no culmina en violencia o en muerte. Pienso en el sorprendente final de "Marta y Hortensia" de Enrique Gómez Carrillo (Almas y cerebros. París: Garnier, 1919). El hecho de que el relato trate de lesbianas (homosexuales menos amenazadoras) acaso explique el final relativamente inocuo.

12 Julio Orlandi Araya y Alejandro Ramírez Cid resumen la recepción de la novela en Chile con términos típicamente patológicos: "Contradictorios en extremo resultan los juicios críticos en torno al sentido vital de Pasión y muerte del cura Deusto. Oscilan desde la interpretación de la obra como un capítulo autobiográfico de un invertido frustrado, hasta la teoría del hipersensible sexualmente introvertido que busca en la debilidad - Zahir, Gatita y el Aceitunita eran unos simples niños cuando él los conoció- la satisfacción platónica de las más variadas tendencias" (23).
} 
norte, región convencionalmente mitificada dentro del imaginario hispano como bravía, heroica, económica y étnicamente "pura". El país vasco es el allá de la novela, la norma que pauta las costumbres y las conductas por comparación insuficientes porque la novela transcurre aqui, en Sevilla, lugar de cruce por excelencia, no sólo por ser primer puerto hacia América, brecha por donde fluye España hacia las colonias, sino por ser lugar de diversidad étnica e hibridez cultural, de ambigüedad y de mezcla. ${ }^{13}$ El Aceitunita proviene de madre gitana y de padre judío, mezcla que, no por azar, se considera transgresiva: "La madre de Pedro Miguel, ya viuda y con un hijo casi hombre, ese sí, gitano por todos cuatro costados, había vuelto a unirse con un judío, y éste y ella convivieron estupefactos de violar sus respectivas supersticiones"(40). Mezcla marginal por excelencia, el muchacho tiene cutis moreno, pelo castaño, ojos improbablemente azules (o verdes, según qué página se lea). Es un "churumbelo que, circunciso y todo, balbuceaba letanías a la virgen cristiana" (41), y que, cuando canta el Angelus, "conservaba algo de islamita; la voz de un neófito-efebo, ambigua, y por lo mismo, de un misterioso encanto"(33). De pie junto a una ventana, El Aceitunita parece "aquel efebo andaluz que un califa cordobés llamara Espada, porque sus ojos, decía, le habían traspasado el corazón"(135). La orientalización se extiende a la ciudad misma, sus edificios, memorablemente evocados en el calor de la siesta:

La añoranza con que el vasco recordaba reiteradamente su Vasconia podía ser una advertencia de su instinto. La canícula había inflamado el zafiro del cielo de Sevilla hasta hacer de él un carbunclo; las palmeras no daban sombra, las fachadas blancas reverberaban, la calle de Sierpes estaba cubierta por velas de buque. El Africa había atravesado el Estrecho y, por Algeciras, se había metido de rondón en sus antiguas dependencias. Una brasa oculta en el minúsculo pebetero de las amapolas parecía tostar chirriando su opio; los claveles destilaban almizcle; las rosas chorreaban vainilla; pero trascendía sobre todo a miel, como si los panales se hubiesen fundido; y debían de ser las abejas sin colmena las que producian ese aturdidor murmullo que, como el de las olas en los caracoles marinos, tal vez no estuviese, a la postre, sino en los oídos de los que sufrían esta insolación.

Los patios, bajo sus tiendas de lona, con sus hamacas de esparto, eran como cubiertas entoldadas de navíos durante la travesía del Mar Rojo; el propio caño de agua se amodorraba; $y$ con las persianas corridas, en la penumbra sofocante de las habitaciones estucadas, y embaldosadas, muchas veces de azulejos, trataban los moradores de atrincherarse contra aquel asedio equinoccial $[\ldots]$ (45).

Así como D’Halmar se disfraza con capa y sombrero cordobés en Andalucía, también sus personajes se visten, se trasvisten y se desvisten con sorprendente frecuencia. Pedro Miguel, cuyo apodo, El Aceitunita, ya presenta, como al descuido, un cruce de géneros, se disfraza de Niño Jesús para la procesión pascual de Deusto; de árabe para el baile de carnaval que da el poeta Giraldo (otra figura sombría a quien se compara explícitamente con Dorian Gray); de gitano cuando baila flamenco por primera vez en el teatro. Por su parte, el cura vasco, patéticamente empeñado en mantener límites, intenta disfrazar al sur de norte,

\footnotetext{
${ }^{13}$ Como escribe James Fernández: "A lo largo de los siglos dieciséis y diecisiete la ciudad fue alabada tanto como censurada por su diversidad y promiscuidad. 'Una nueva Babilonia' era epíteto habitual para Sevilla; Santa Teresa, entre otros, llamó a la ciudad un 'infierno'” (978). Hay ecos evidentes de esa reputación en las descripciones de D’Halmar de la ciudad.
} 
corregir la "musulmana tolerancia"(16) simplificando las ceremonias religiosas, despojando la iglesia de ornamentos, y, como de paso, prohibiendo la entrada a las mujeres que previamente se ocupaban de adornar con exceso la iglesia. ${ }^{14}$ La casa parroquial se disfraza de Algorta, espartano lugar de origen: "los objetos habían tomado un vago aspecto de allá [...] y en el fondo, el cura Deusto esperaba ver extenderse esta transformación hacia otras cosas"(16). Pero el vestir, desvestir y travestir también funcionan en dirección opuesta. Cediendo a los ruegos de su protegido de que vayan juntos al circo, Deusto troca la sotana norteña por el traje de señorito meridional: "A la luz de una bujía, frente al pequeño espejo, un esbelto señorito, vestido de negro, se arreglaba el lazo de la corbata, y cuando, tomando la boina y la capa, se encontraron fuera, el gitanillo no podía hacerse a la idea que ese su acompañante joven y airoso era el adusto sacerdote que él había tenido siempre por viejo" (122).

Sólo cabe conjeturar las razones por las cuales D'Halmar eligió Sevilla para repensar lo hispano y no, digamos, Castilla (donde lo hispano ya se había pensado y se estaba pensando por parte de los españoles mismos). Quizás fuera un homenaje a la espagnolade, la aceptación de la vieja y exitosa receta: Pasión y muerte remite inevitablemente a la Carmen de Mérimée, hasta en sus atribuciones étnicas: el deseante es vasco, el objeto de deseo, andaluz; el norte es económico y reprimido, el sur es derrochador, equívoco, e indigno de confianza. O quizás, al elegir Sevilla, ciudad abierta a América, D’Halmar invertía el gesto español de colonización, sometiendo a esa madre patria que se jactaba de haber redescubierto a la mirada desfamiliarizadora del orientalismo, transformando el lugar fundacional de la empresa imperial en lugar baratamente exótico. ¿O se trata acaso de algo diferente?

Quisiera volver por un momento a la noción de "lo nuestro", expresión presente en más de un momento de mi texto y cargada de connotaciones muy diversas. Para Manuel Ugarte, en el epígrafe de este trabajo, la primera persona plural señala una comunidad de viajeros hispanoamericanos empeñados en "encontrarnos con nosotros mismos [...] para encontrar la nacionalidad superior"; para Vasconcelos, la primera persona plural ancla "nuestro" pasado hispánico; para D’Halmar, sirve para confirmar su recuperación de España: "es de nosotros y de mí mismo que me ocupo". Pero el uso que hace el Aceitunita del término como en "me voy sobre todo porque 'lo nuestro' [...] no podía ya prolongarse" (219) _ apunta a una comunidad muy otra, no habitualmente presente en los procesos de organización nacional, una comunidad ya anunciada al comienzo del texto, con el uso emblemático de la primera persona. Cuando llega Deusto a Sevilla por primera vez se detiene inquieto ante La Giralda:

[A] su imaginación de hombre del Norte chocaba como un símbolo esa Fortísimma turris nomen Domina que sugiere el vértigo y que no puede escalarse solo. Una voz viva y cantante vino a hacerle descender desde las alturas de su divagación.

—Subiremos juntos- decidía el niño (9-10; énfasis mío).

\footnotetext{
${ }^{14} \mathrm{La}$ única figura femenina que permanece en la casa parroquial es la fiel ama de llaves, figura tutelar que ya ha aparecido, en otro avatar, en Gatita. Aquí, no por casualidad, la criada se llama Mónica, como para acentuar su santa devoción materna.
} 
¿Por qué entonces no ver el recurso de D’Halmar al orientalismo (un orientalismo cuya explotación colonialista no pretendo negar) como la única manera de crear un espacio para ese muy particular "lo nuestro"? ¿Por qué no ver la elección de Sevilla, de una Sevilla exótica, de castañuelas y de incienso, como manera de crear un espacio de diferencia muy visible - muy espectacular, muy cursi- donde decir lo que no puede decirse en la ficción hispanoamericana de la época: un espacio extra-ordinario donde la homosexualidad no sólo "pasa" (aunque marginalmente) sino que puede pasar a la ficción? ${ }^{15}$ Esta forma de orientalismo, en Pasión y muerte del cura Deusto, no es por cierto, para citar de nuevo a D’Halmar, "un pueril exotismo de jugar al [español]" (o no sólo eso) sino una necesidad cultural: una manera, sí, de conjurar "no sé qué obscura suerte de la cual apenas si me atrevo a ocuparme", de conjurarlo sacándolo a la luz, haciéndolo público aun cuando se lo disfraza, sacándolo de ese "abismo secreto" y privado al que lo condena Díaz Arrieta y adonde querría relegarlo la crítica. Al orientalizar a la patria, D'Halmar logra a la vez manifestar el deseo homosexual en un "afuera" exótico y, con el mismo gesto, traerlo de vuelta a casa, una casa que los nacionalistas hispanoamericanos y defensores de la hispanidad latina y "pura", no reconocerian y menos reclamarían: "[L]os que sentimos el alma de la raza - escribe memorablemente Manuel Gálvez, recurriendo una vez más a nociones de "lo nuestro"-, los que la hemos visto vagar en las callejuelas de las ciudades castellanas, miramos como cosas exóticas los arabescos de la Alhambra, los jardines del Generalife, todos aquellos encantos que nos muestran un pueblo sensual y afeminado. La España castiza, aunque vieja y ruinosa, la llevamos dentro; la España africana está muy lejos de nosotros" (Gálvez 258; énfasis mío). ${ }^{16}$ D'Halmar añadiría: "No tanto".

En conflicto con construcciones de España como las de Gálvez, Pasión y muerte del cura Deusto problematiza una lectura unívoca, heteronormativa de lo hispano, llamando así la atención sobre la inevitable represión de todo discurso nacional hegemónico, discurso dentro del cual la diferencia sexual no podía, no debía - o no puede, no debe - caber, donde "lo nuestro", para volver al Aceitunita, por cierto no puede prolongarse y termina, si no bajo las ruedas de un ferrocarril, entonces en el closet de las ideologías nacionales.

\footnotetext{
${ }^{15}$ Los modos de hacer que la homosexualidad "pase" en la ficción de los años veinte y treinta son, desde luego, contados. Alfonso Hernández Catá, en El ángel de Sodoma, la otra novela homoerótica a la que me he referido, cuida de presentar a su personaje como caso patológico, presentación favorecida por un prólogo de Gregorio Marañón y un epílogo del Dr. Luis Giménez de Azúa que procuran medicalizar el texto y controlar su recepción. La orientalización elegida por D'Halmar, si bien problemática, es menos homofóbica. Que el deseo homosexual sólo puede manifestarse dentro de lo exótico es evidente en toda la ficción de D'Halmar. Aún aquellos relatos que no transcurren en lugares exóticos sufren una vuelta de tuerca distanciadora. En "Valerio Dux", por ejemplo, relato de Los alucinados que transcurre en París, el niño andrógino del que se enamora el protagonista (y por quien se suicida) es de Bretaña, región construida en el cuento como alteridad exótica de la capital francesa.

${ }^{16}$ A lo largo de El solar de la raza Gálvez insiste en negar la influencia árabe en España, incluso (por difícil que pareza) en Andalucía: "Hoy sólo existe lo árabe en España como ruina arqueológica" (240) y "En Sevilla, que suele ser considerada como una ciudad africana, lo árabe es insignificante" (249).
} 


\section{BiBLIOGRAFIA}

Acevedo, Ramón L. Augusto D'Halmar, novelista: Estudio de Pasión y muerte del cura Deusto. Puerto Rico: Editorial Universitaria, 1976.

Apter, Emily. "Female Trouble in the Colonial Harem". Differences 4/1 (1992): 205-224. Asquerino, Eduardo. "Nuestro pensamiento". La América (Madrid, 24-25 marzo 1857). Boone, Joseph A. "Vacation Cruises; or, The Homoerotics of Orientalism". PMLA 110/1 (1995): 89-107.

D’Halmar, Augusto. Los alucinados. Santiago: Ercilla, 1935. Antología de Augusto D'Halmar. El hermano errante. Selección y prólogo de Enrique Espinoza. Santiago: Zig-Zag, 1963. Gatita, Obras escogidas. Santiago: Editorial Andrés Bello, 1970. "Joaquín Edwards Bello y su novela española". Atenea XI (July 1929): 497-500. Nirvana. Viajes al Extremo-Oriente. Barcelona: Editorial Maucci, n.d. Pasión y muerte del cura Deusto [1924]. Santiago: Nascimento, 1969. "El reportaje que nadie nos hace nunca". Antología de Augusto D'Halmar. El hermano errante. Selección y prólogo de Enrique Espinoza. Santiago: Zig-Zag, 1963. 233-242.

La sombra del humo en el espejo, Obras escogidas. Santiago: Editorial Andrés Bello, 1970.

Díaz Arrieta, Hernán. Los cuatro grandes de la literatura chilena del siglo XX. Santiago: Zig-Zag, 1963.

Edwards Bello, Joaquín. Recuerdos de un cuarto de siglo. Santiago: Zig-Zag, 1966.

Espinosa, Enrique. "Prólogo". Antología de Augusto D'Halmar. El hermano errante. Santiago: Zig-Zag, 1963. 9-31.

Fernández, James. “The Bonds of Patrimony: Cervantes and the New World". PMLA 109/ 5 (1994): 969-981.

Gálvez, Manuel. "Las sombras de Taric". Diwan modernista: Una visión del Oriente. Abdellah Djbilou, ed. Madrid: Taurus, 1986. 248-258.

Garber, Marjorie. Vested Interests: Cross Dressing and Cultural Anxiety. Nueva York: Routledge, 1992.

Gómez Carrillo, Enrique. "Marta y Hortensia". Almas y cerebros. París: Garnier, 1919. $73-$ 80.

Hernández Catá, Alfonso. El ángel de Sodoma. Prólogo del Dr. Gregorio Marañón. Epílogo del Dr. Giménez de Azúa. Valparaíso: El Callao, 1929.

Koestenbaum, Wayne. Double Talk: The Erotics of Male Literary Collaboration. Nueva York y Londres: Routledge, 1989.

Montenegro, Ernesto. "Prólogo a Augusto D'Halmar". Capitanes sin barco. Santiago: Ediciones Ercilla, 1934.

Orlandi Araya, Julio y Alejandro Ramírez Cid. Augusto D'Halmar. Obras, estilo, técnica. Santiago: Editorial del Pacífico, 1959.

Reyles, Carlos. El embrujo de Sevilla [1922]. Montevideo: Editorial Kapelusz, 1980.

Rodó, José Enrique. Obras completas. Introd. y notas de Emir Rodríguez Monegal. Madrid: Aguilar, 1967. 
Said, Edward. Orientalism [1978]. Nueva York: Vintage Books, 1979.

Santiván, Fernando. Memorias de un tolstoyano, Obras completas. Santiago: Zig-Zag, 1965.

Sebreli, Juan José. "Historia secreta de los homosexuales porteños". Perfil II/27 (Buenos Aires, 1983): 6-13.

Suárez, José León. Mitre y España. A propósito de la Exposición Iberoamericana de Sevilla. Madrid: Maestre, 1929.

Ugarte, Manuel. Escritores iberoamericanos de 1900. Santiago: Editorial Orbe, 1943.

Unamuno, Miguel de. "Recuerdo de su última estada en París". Nosotros XIX/199(1925): 429-432.

Vasconselos, José. Ulises criollo, Memorias, I. México: Fondo de Cultura Económica, 1982. 